\title{
Bedrock erosion and relief production in the northern Flinders Ranges, Australia
}

\author{
Mark Quigley, '* Mike Sandiford,' Keith Fifield ${ }^{2}$ and Abaz Alimanovic' \\ School of Earth Sciences, The University of Melbourne, Australia \\ 2 Research School of Physical Sciences and Engineering, Australia National University, Canberra, Australia
}

*Correspondence to: Mark Quigley, School of Earth Sciences, The University of Melbourne, VIC. 3010, Australia. E-mail: m.quigley2@pgrad.unimelb.edu.au

Received 25 April 2006;

Revised 22 September 2006;

Accepted 5 October 2006

\begin{abstract}
Cosmogenic ${ }^{10} \mathrm{Be}$ concentrations in exposed bedrock surfaces and alluvial sediment in the northern Flinders Ranges reveal surprisingly high erosion rates for a supposedly ancient and stable landscape. Bedrock erosion rates increase with decreasing elevation in the Yudnamutana Catchment, from summit surfaces (13.96 \pm 1.29 and $\left.14.38 \pm 1.40 \mathrm{~m} \mathrm{Myr}^{-1}\right)$, to hillslopes $\left(17.61 \pm 2.21\right.$ to $\left.29 \cdot 24 \pm 4.38 \mathrm{~m} \mathrm{Myr}^{-1}\right)$, to valley bottoms $(53 \cdot 19 \pm 7.26$ to $227.95 \pm$ 21.39 $\mathrm{m} \mathrm{Myr}^{-1}$ ), indicating late Quaternary increases to topographic relief. Minimum cliff retreat rates $\left(9 \cdot 30 \pm 3.60\right.$ to $\left.24 \cdot 54 \pm 8 \cdot 53 \mathrm{~m} \mathrm{Myr}^{-1}\right)$ indicate that even the most resistant parts of cliff faces have undergone significant late Quaternary erosion. However, erosion rates from visibly weathered and varnished tors protruding from steep bedrock hillslopes $(4 \cdot 17 \pm$ 0.42 to $14.00 \pm 1.97 \mathrm{~m} \mathrm{Myr}^{-1}$ ) indicate that bedrock may locally weather at rates equivalent to, or even slower than, summit surfaces. ${ }^{10} \mathrm{Be}$ concentrations in contemporary alluvial sediment indicate catchment-averaged erosion at a rate dominated by more rapid erosion (22.79 $\pm 2.78 \mathrm{~m} \mathrm{Myr}^{-1}$ ), consistent with an average rate from individual hillslope point measurements. Late Cenozoic relief production in the Yudnamutana Catchment resulted from (1) tectonic uplift at rates of 30-160 $\mathrm{m} \mathrm{Myr}^{-1}$ due to range-front reverse faulting, which maintained steep river gradients and uplifted summit surfaces, and (2) climate change, which episodically increased both in situ bedrock weathering rates and frequency-magnitude distributions of large magnitude floods, leading to increased incision rates. These results provide quantitative evidence that the Australian landscape is, in places, considerably more dynamic than commonly perceived. Copyright (c) 2006 John Wiley \& Sons, Ltd.
\end{abstract}

Keywords: Australia; cosmogenic; erosion; neotectonics; bedrock; landscape evolution; climate change

\section{Introduction}

The evolution of mountainous topography results from the dynamic interplay between tectonic forces, climate and erosion. For relief to develop in mountainous catchments, rates of fluvial incision into the landscape must exceed erosion rates on adjacent summit surfaces. Intervening hillslopes provide the bridge between these features, and may take on forms reflecting the relative rates of valley floor and summit surface erosion, as well as their internal lithologic and structural characteristics. In order to examine how mountainous landscapes respond to the tectonic and climatic forces imposed upon them, it is therefore critical to establish quantitative measures of bedrock erosion rate at summit surfaces, hillslopes and valley floors.

For a continent generally regarded for its low, flat and old landscapes (Twidale and Bourne, 1975; Twidale, 2000; Ollier, 1978; Bierman and Caffee, 2002; Twidale and Campbell, 2005) parts of Australia contain surprisingly rugged and mountainous topography. One such region is the Flinders Ranges, where local relief commonly exceeds $600 \mathrm{~m}$ and sharp, rock mantled ridgelines are incised by steep, narrow gorges. Both the time at which this relief formed and processes responsible for its development are unknown. Recent work suggests that a significant portion of the present relief may have developed since the terminal Miocene in response to intraplate tectonism and uplift (Sandiford, 2003; Célérier et al., 2005; Quigley et al., 2006a; Quigley et al., in review-a, in review-b), although other workers inferred that the ranges were uplifted and eroded prior to the Eocene (Veevers and Conaghan, 1984; Gallagher et al., 1994; 
Mitchell et al., 2002; Twidale and Campbell, 2005). Until recently, there was no quantitative way to assess whether modern erosion rates are rapid and spatially variable, which would suggest recent increases to relief, or spatially uniform and slow, which would suggest steady-state lowering of ancient topography.

In situ produced cosmogenic nuclides $(\mathrm{CN})$ such as beryllium-10 $\left({ }^{10} \mathrm{Be}\right)$ provide novel insights into the rates of mountain erosion. $\mathrm{CN}$ concentrations in bare bedrock surfaces may be used to determine erosion rates (see, e.g., Lal, 1991; Small et al., 1997; Bierman and Caffee, 2002; Belton et al., 2004; Stock et al., 2005) and date strath terraces (see, e.g., Burbank et al., 1996; Reusser et al., 2004) over $>1000-1000000$ year timescales. CN concentrations in alluvial sediment may be used to determine catchment-averaged erosion rates (see, e.g., Granger et al., 1996; Bierman and Steig, 1996; Vance et al., 2003; Binnie, 2004). Providing CN concentrations are accompanied by robust geomorphic observations and data, these applications can reveal much about the timing, magnitudes and processes of relief generation in mountainous regions.

This paper provides a quantitative analysis of the rates and processes of bedrock erosion for a mountainous catchment floored by resistant, variably foliated and ubiquitously jointed granitic bedrock. We describe and compare the erosional processes operating at summit surfaces, hillslopes and valley floors and use ${ }^{10} \mathrm{Be}$ concentrations in bedrock and alluvial sediment to provide a measure of the rates at which these processes operated in recent (late Quaternary) geologic time. Our results are placed into tectonic and climatic contexts in order to explain how an anomalously rugged, high relief mountain belt has developed in the middle of a continent generally known for its tectonic quiescence and climatic aridity.

\section{The Flinders Ranges}

The Flinders Ranges form part of an upland system extending some $600 \mathrm{~km}$ inland from the southern coast of South Australia to the Lake Eyre Basin (Figure 1). Virtually all of the ranges are above $300 \mathrm{~m}$ in elevation and peak elevations locally exceed $\sim 1100 \mathrm{~m}$. In the northern Flinders Ranges, relief within granite and quartzite catchments such as the Yudnamutana Gorge is locally in excess of $600 \mathrm{~m}$, defining one of the most dramatic and topographically youthful landscapes of the Australian continent (Célérier et al., 2005). The Flinders Ranges are surrounded by lowelevation, low-relief regions dominated by internally draining playa lake systems (Lakes Frome, Torrens and Eyre) and isolated granitic inselbergs (Figure 1).

The bedrock geology includes resistant and steeply dipping Neoproterozoic and Cambrian quartzite and sandstone, more easily eroded limestones, shales and argillites, and underlying Proterozoic metasedimentary rocks and granite (Coats, 1973; Stevens and Corbett, 1993; Preiss, 1999). Many of the Flinders Ranges large-scale landforms reflect erosional competency contrasts between different stratigraphic units, with high relief areas typically underlain by granite, quartzite and/or sandstone bedrock and lower relief areas underlain by mixed shale-limestone-sandstone sequences (Figure 2). The base level of fluvial systems, elevations of regional summit surfaces and resultant maximums in relief are therefore primarily governed by erosion rates of the most resistant lithologies in the catchment system.

Summit surfaces in the northern Flinders Ranges are locally overlain by Cretaceous fluvial sequences, indicating the relief must be post-Mesozoic. An apparent lack of young tectonic activity led some workers to suggest that the topography dates back to the early Cenozoic (see, e.g., Veevers and Conaghan, 1984). However, range-bounding Pliocene alluvial fan sequences overlie Miocene low-energy lacustrine sequences, indicating a terminal Miocene shift to coarse sedimentation that Callen and Tedford (1976) interpreted to mark the initiation of uplift of the Flinders Ranges. The recognition of a number of range bounding reverse faults with demonstratable and significant Quaternary displacements (Sprigg, 1945; Williams, 1973; Belperio, 1995; Sandiford, 2003; Célérier et al., 2005; Quigley et al., 2006a) led some workers to attribute 30 per cent (Quigley et al., 2006a) to 50 per cent (Sandiford, 2003) of the present day relief to late Miocene to Recent tectonic uplift.

Currently, the Flinders Ranges form one of the most seismically active regions in the Australian continent (Figure 1), with hundreds of small earthquakes recorded yearly and five magnitude $>5$ earthquakes recorded in the past century (Greenhalgh et al., 1994). Approximately east-west oriented maximum compressive stress orientations derived from focal-plane solutions of historical earthquakes (Clark and Leonard, 2003) corroborate inferred palaeo-stress orientations from kinematic analyses of Pliocene and Quaternary faults (Sandiford, 2003; Quigley et al., 2006a), implying that the modern, compressional tectonic regime has been active since at least the Pliocene.

\section{Study Area}

This study is focused on the eastern portion of the Yudnamutana Catchment in the northern Flinders Ranges (Figure 2), where Yudnamutana Creek has incised a steeply sided valley into Paleoproterozoic granite (Coats, 1973). 


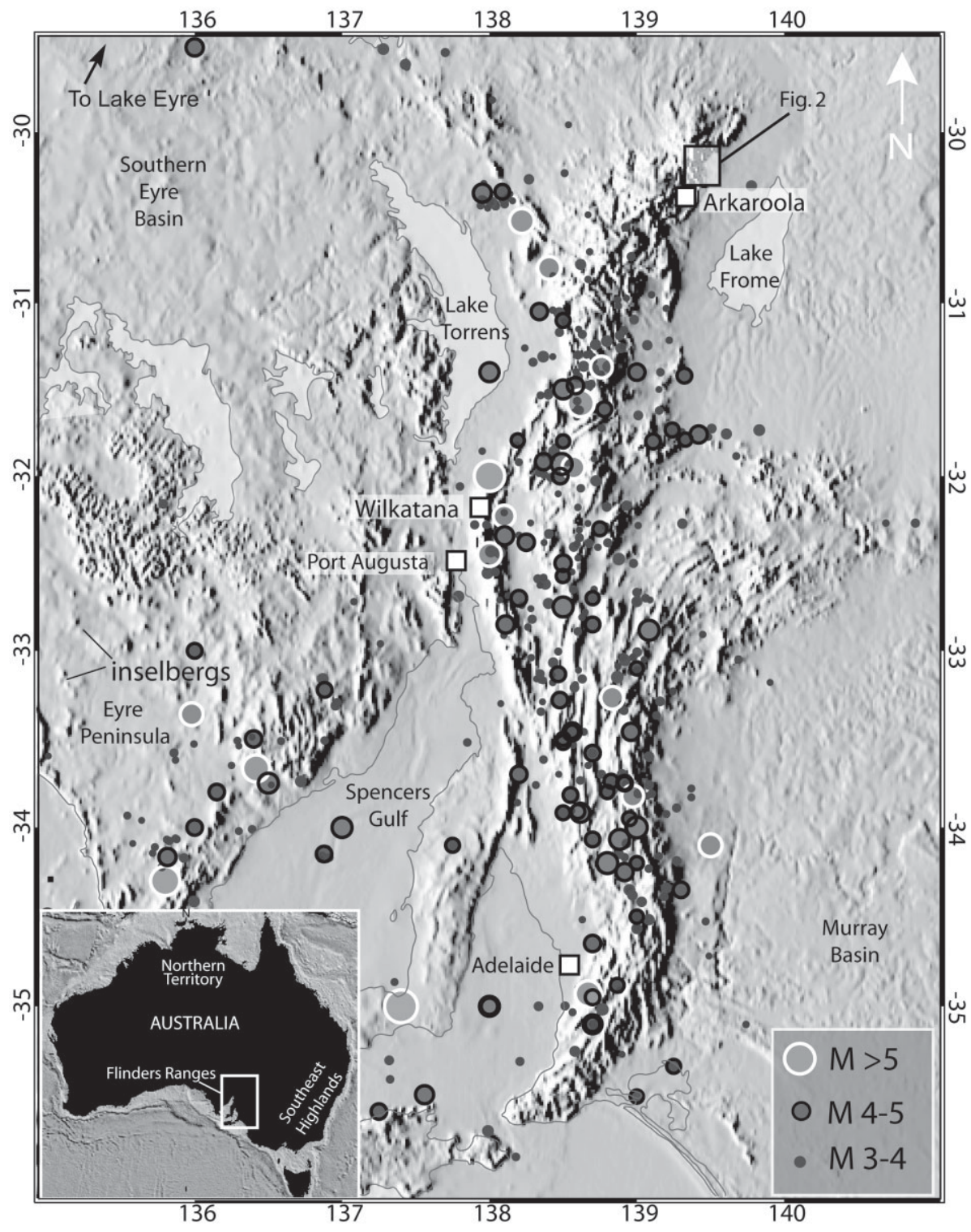

Figure I. Digital elevation map of South Australia including the Flinders Ranges and surrounding playa lake systems. The Superimposed historical seismicity pattern shows strong correspondence between earthquake distribution and the ranges. $M=$ earthquake magnitude. Location of Eyre Peninsula inselbergs shown. Inset: map of Australia showing location of Flinders Ranges.

Granite is exposed at all elevations throughout the study area and is relatively compositionally and texturally homogeneous, containing only small (1-3 m thick), localized rafts of schist and gneiss. The meandering course of Yudnamutana Creek has exposed flanking cliff faces and hillslopes of all aspects. Large bedrock tors continually expose hillslopes and cliff faces through a $360^{\circ}$ azimuthal range. The Yudnamutana area thus provides an excellent locality to observe hillslope erosion in a variety of orientations within a relatively lithologically homogeneous medium.

The Yudnamutana Catchment resides in the hanging wall of the Paralana Fault (Figures 2 and 3). A number of exposures of the fault along the eastern range front provide clear evidence for Pliocene to Quaternary movements. Roughly $4 \mathrm{~km}$ northeast of the Paralana Hot Springs (Figure 2), Proterozoic quartzite has been thrust along a $\sim 25^{\circ} \mathrm{W}$ dipping fault plane over a Pliocene alluvial conglomerates and unconsolidated Holocene (?) hillslope colluvium (Figure 3(a); Sandiford, 2003; Célérier et al., 2005). Roughly 8 km south of the Paralana Hot Springs, Neoproterozoic 


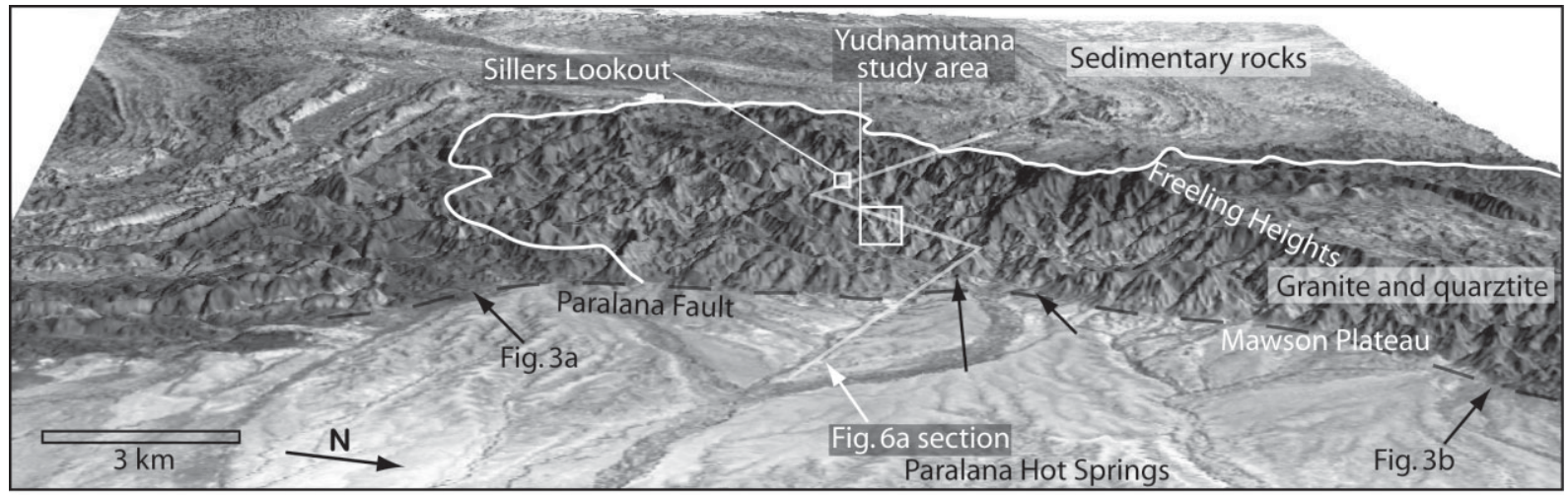

Yudnamutana Ck

Figure 2. Digital elevation map of the northern Flinders Ranges including the Yudnamutana study area, looking west. Changes in range morphology show strong correlation with bedrock lithology, from more massive, rugged granite and quartzite catchments to strike-ridge topography corresponding to mixed sedimentary sequences.
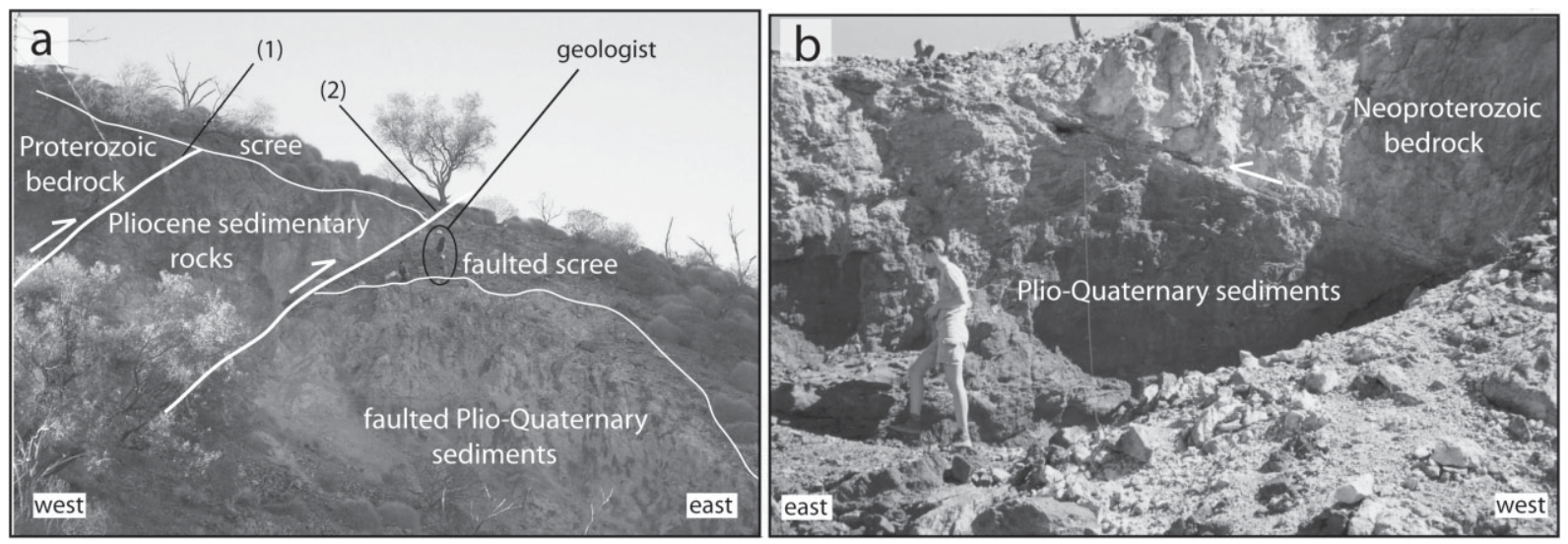

Figure 3. Paralana Fault exposures in the Yudnamutana region. Locations of fault exposures shown in Figure 2. (a) Reverse faults placing Proterozoic bedrock above Pliocene sedimentary rocks (I) and Pliocene sedimentary rocks above Plio-Quaternary sediments and loosely consolidated modern hillslope scree (2). Given the youthfulness of the faulted scree deposit, faulting along (2) is concluded to have occurred in the late Quaternary. (b) Low-angle reverse fault placing Neoproterozoic marble above unmetamorphosed, weakly consolidated ferriginous sandstone and gravel of Plio-Quaternary age.

bedrock is similarly thrust along a $\sim 30^{\circ} \mathrm{W}$-dipping fault plane over ferruginous sandstone and conglomerate of probable Pliocene age (Figure 3(b); Sandiford, 2003). Pliocene and Quaternary footwall sediments obtain thicknesses of $\sim 150 \mathrm{~m}$ (Callen and Tedford, 1976), implying the Yudnamutana Catchment has incurred more than $\sim 150 \mathrm{~m}$ of uplift relative to adjacent piedmont surfaces since the early Pliocene (Sandiford, 2003; Célérier et al., 2005). The region experiences a number of small earthquakes yearly, implying that faults such as the Paralana Fault may be presently active.

Today's climate in the Yudnamutana region is generally hot and arid (Table I; www.bom.gov.au). Mean daily maximum temperatures at Arkaroola in summer are $>32{ }^{\circ} \mathrm{C}$, although mean daily minimum winter temperatures are cold $\left(<5^{\circ} \mathrm{C}\right)$. Mean annual precipitation in the region is weakly orographic, ranging from less than $200 \mathrm{~mm}$ in the Frome Basin to $254 \mathrm{~mm} \mathrm{yr}^{-1}$ at Arkaroola and more than $300 \mathrm{~mm} \mathrm{yr}^{-1}$ on higher ridges (Table I). Annual evaporation exceeds $2000 \mathrm{~mm}$ and as a consequence there are no permanent water bodies in the region other than a few small spring-fed streams. Vegetation is sparse aside from large River Red Gum trees that grow along the present creek beds.

Quaternary climates in the region were arid and generally cooler than present. Temperatures during the Last Glacial Maximum ( 18-24 ka) may have been as much as $8-10{ }^{\circ} \mathrm{C}$ colder in the region (Miller et al., 1997; Williams et al., 2001) and it is therefore probable that winter temperatures were below $0{ }^{\circ} \mathrm{C}$ at this time. No evidence for Quaternary glaciation has been observed in the Flinders Ranges, although the inferred cold temperatures and heavily jointed bedrock suggest that periglacial processes (i.e. frost shattering) operated during glacial periods (Williams, 1973). 
Table I. Selected climate data from South Australian localities. See www.bom.gov.au for more data

\begin{tabular}{lccccc}
\hline Location & $\begin{array}{c}\text { Max summer } \\
\text { daily temp } \\
\text { (Jan) }\end{array}$ & $\begin{array}{c}\text { Min winter } \\
\text { daily temp } \\
\text { (July) }\end{array}$ & Mean & Median & Rain days $\mathbf{~ y r}^{-1}$ \\
\hline Arkaroola & $34.0^{\circ} \mathrm{C}$ & $3.2^{\circ} \mathrm{C}$ & 254.3 & 220.8 & 34.1 \\
Port Augusta & $32.0^{\circ} \mathrm{C}$ & $7.3^{\circ} \mathrm{C}$ & 210.5 & 196.6 & 39.9 \\
Eyre Peninsula & $31.7^{\circ} \mathrm{C}$ & $6.5^{\circ} \mathrm{C}$ & 326.6 & 316.6 & 87.9 \\
\hline
\end{tabular}

Data obtained from the Australian Bureau of Meteorology, www.bom.gov.au

\section{Bedrock Erosion}

We divided landforms composing the Yudnamutana Catchment into three components: summit flats, hillslopes and valley bottoms. A subhorizontal envelope intersecting individual granite and quartzite summit flats defines a regional paleo-planation surface ranging in elevation from 550 to $900 \mathrm{~m}$ above sea level (Freeling Heights Surface; Figure 2). We focused our studies on the Sillers Lookout summit surface, Yudnamutana Tor, Yudnamutana Creek and intervening hillslopes that connect these features (Figure 2).

\section{Summit flats}

Individual summit flats range in area from $<20 \mathrm{~m}^{2}$ (Sillers Lookout, Yudanamutana Tor) to $>50 \mathrm{~km}^{2}$ (Mawson Plateau; Figure 2) and are typically convex upward in profile. The flats are dominated by heavily jointed in situ bedrock surfaces and small blocks (up to $\sim 15 \mathrm{~cm}$ diameter) that have become dislodged from the outcrop along joint planes. A thin (5$20 \mathrm{~cm}$ ), patchy regolithic layer consisting of gravel to silt-sized sediment is locally developed. Small bedrock tors (knobs that protrude through the regolith mantle) extend up to $50 \mathrm{~cm}$ above adjacent surfaces (Figure 4(a)). Tor tops locally exhibit millimeter to centimeter scale exfoliation of thin sheets and granular disintegration, indicating that bedrock erosion has occurred via a combination of in situ weathering and joint controlled rock breakup. The gentle slopes and low relief associated with summit surfaces inhibit transport by gravity-driven mass wasting processes, such as block fall and landsliding. Instead, weathering and rock breakup have reduced the coherency and rock size of bedrock material until it is transportable by rainfall-aided hillslope or eolian processes. The predominance of in situ bedrock at summit surfaces suggests that the rates of summit flat lowering are primarily limited by rates of in situ weathering.

\section{Hillslopes, cliff faces and talus slopes}

Hillslopes within the Yudnamutana Catchment range from long (1-2 km) continuous slopes that are highly stepped in profile to steeply inclined to vertical bedrock cliffs of 2-200 $\mathrm{m}$ height that are capped by horizontal bedrock surfaces. Steeply dipping talus slopes are frequently developed along the base of cliffs and locally developed on long hillslopes. The 'stepped' profile associated with long hillslopes is defined by subhorizontal bedrock benches and intervening, moderately dipping, mixed bedrock and colluvial hillslopes. Subhorizontal bedrock benches are partially capped by thin, rocky regolith and display evidence for similar in situ and rock breakup processes observed at summit surfaces (Figure 4(b)). Individual benches appear to correlate laterally at similar elevations on a number of hillslopes throughout the Yudnamutana Catchment, implying that they may have formed as regional planation surfaces during earlier phases of range development (Fenner, 1933; Twidale, 1994; Sprigg, 1945). Only the lowermost bedrock bench (Figure $4(\mathrm{c})$ ), located roughly $5 \mathrm{~m}$ above the active creek bed, contains localized evidence for fluvial sculpting in the form of striated and polished surfaces.

Cliff faces are heavily jointed and appear to be most susceptible to rockfall erosion on exposed, jointed surfaces. The size and thickness of rock material eroded from cliff faces, as inferred from unstable material still attached to cliff faces, ranges from $\sim 10 \mathrm{~cm}^{3}$ cubical blocks to $>30 \mathrm{~m}^{2}$ rock slabs with thicknesses $>1 \mathrm{~m}$. The Yudnamutana Tor (Figure 5(a)) provides a $360^{\circ}$ exposure of eroding cliff faces around its entire circumference and therefore presents a unique opportunity to study how hillslope erosion varies with aspect at a single site. Erosional processes and resulting hillslope geometries differ considerably from face to face. The southern cliff face is straight and subvertical, and the dominant erosional process involves the delamination of large bedrock slabs along subvertical foliation planes and joint sets subparallel to the cliff face (Figure 5(b)). A secondary set of joints dips gently into the hillslope and does not 

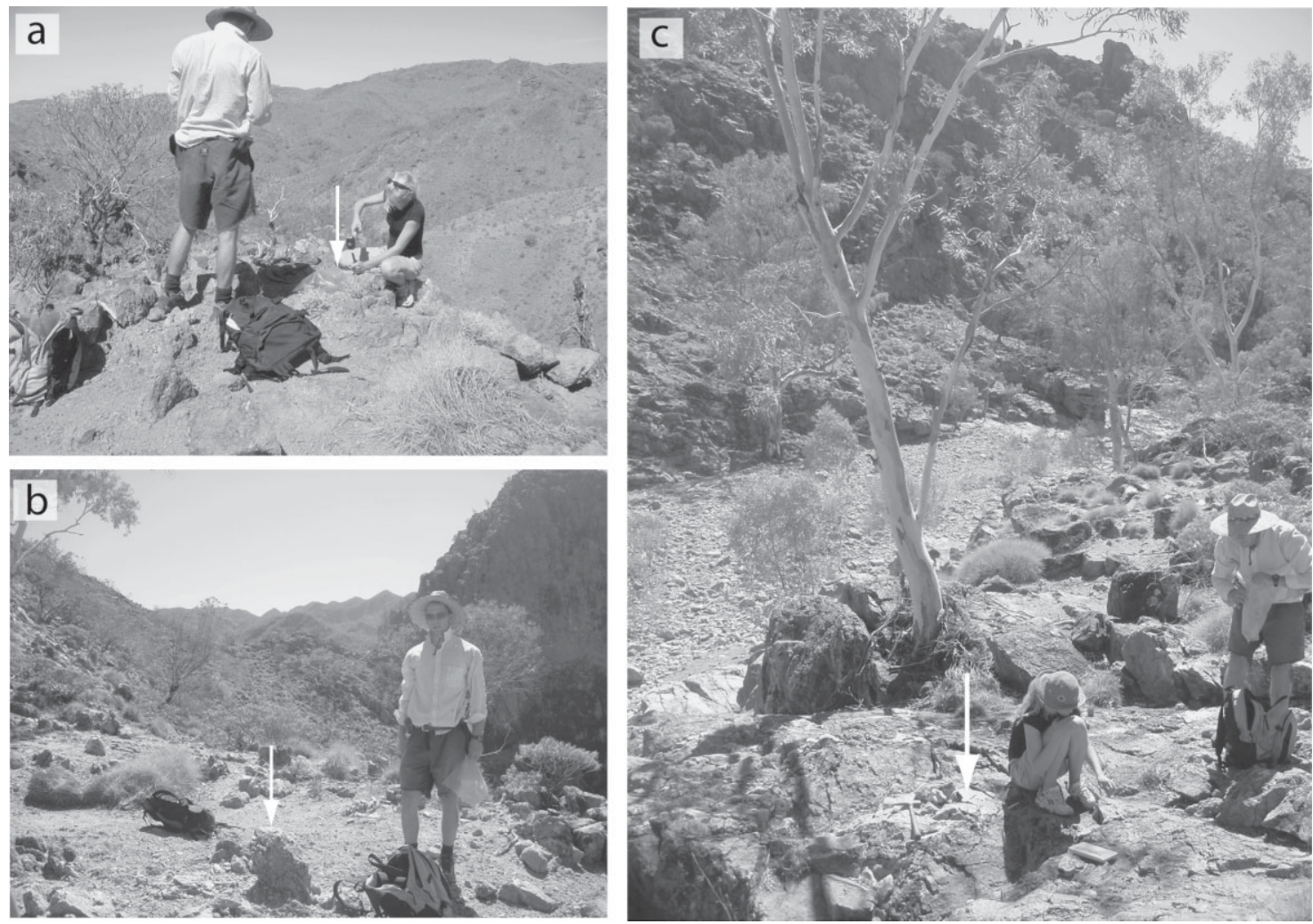

Figure 4. Selected cosmogenic sampling sites (denoted by arrows). (a) Sample site YG06, collected from the top of the Yudnamutana Tor (summit surface). (b) Sample site YG04, collected from the top of a small tor protruding above adjacent bedrock and regolith at a subhorizontal bedrock bench. (c) Sample site YG02, collected from a fluvially polished bedrock strath terrace above Yudnamutana Creek (pictured in background).

appear to exert much influence over the vertical extent of individual slabs still attached to the cliff face. We measured a series of vertical joint spacings and inferred an average slab thickness normal to the cliff face of $\sim 47 \mathrm{~cm}$ (Table II; Figure 5(b)). Slabs are associated with vertical thicknesses of up to $20 \mathrm{~m}$.

The eastern cliff face has a highly irregular, stepped cross-sectional profile, containing interspersed small vertical cliff faces, gently inclined bedrock surfaces and steeply inclined bedrock hillslopes (Figure 5(c)). Erosion occurs primarily through gravity-driven removal of cobble to boulder-sized, joint-controlled cubical bedrock blocks from the hillslope. The subvertical joint sets controlling slab thickness on the southern cliff face are at right angles to the eastern face, and appear to provide only minimal control on horizontal block thickness parallel to the hillslope. Block geometries are governed more prominently by pervasive shallow northeast-dipping and moderately southwest-dipping joint sets (Figure 5(c)).

Table II. Joint measurements from the Yudnamutana Tor

\begin{tabular}{lccc}
\hline Tor face & Mean thickness $\mathbf{( c m )}$ & Avg orientation & $\begin{array}{c}\text { \# of joint } \\
\text { measurements }\end{array}$ \\
\hline South & $47 \pm 15$ & $078 / 87$ & 31 \\
West & $18 \pm 6$ & $340 / 41$ & 40 \\
West & $30 \pm 18$ & $082 / 80$ & 13 \\
North & $49 \pm 22$ & $060 / 88$ & 17 \\
North & $24 \pm 8$ & $300 / 30$ & 20 \\
East & $19 \pm 12$ & $134 / 54$ & 23 \\
East & $20 \pm 15$ & $296 / 24$ & 18 \\
\hline
\end{tabular}



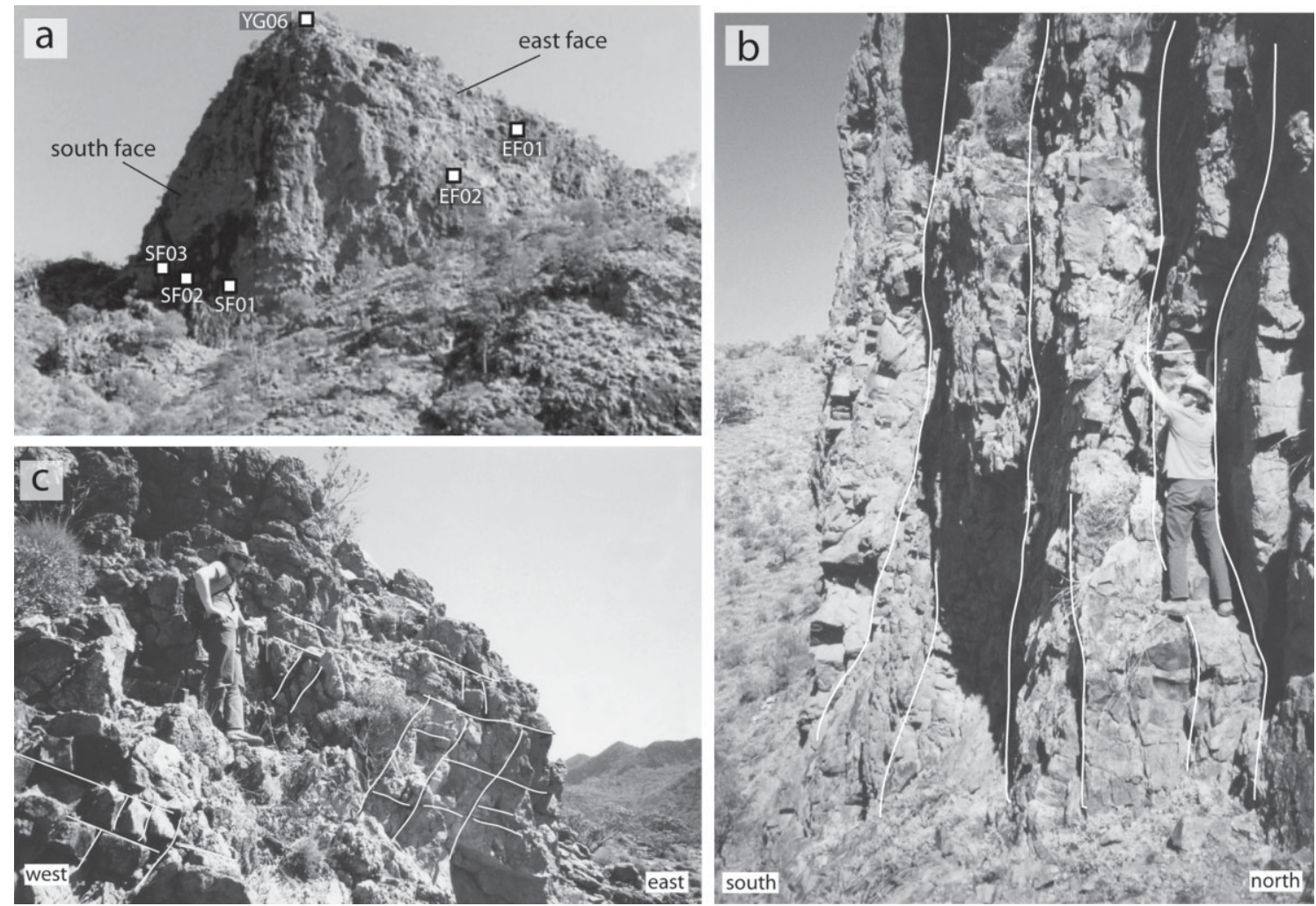

Figure 5. Field photographs and cosmogenic sample locations from the Yudnamutana Tor. (a) Location of cosmogenic sampling sites on the east and south faces of the tor. (b) Measuring subvertical joint sets parallel to the south face; note systematic joint spacing and orientation. (c) Joint sets along the east face, displaying the markedly different spacing and orientation that resulted in distinct hillslope form.

The rugged northern and western cliff faces exhibit evidence for both the block-style erosion and slab-style delamination observed at the eastern and southern faces, respectively. While subvertical joints have allowed a steep profile to develop over much of the northern face, the shallow joint set (Table II) dips away from the hillslope and appears to have generated a more stepped profile than observed at the southern face. Moderately southwest-dipping joint sets observed at the western face also dip away from the hillslope (Table II) and may have played a more prominent role in developing a steeper hillslope there relative to the eastern face. If the joint sets observed at the Yudnamutana Tor are regional in extent, as reconnaissance observations suggest, we predict that the relationships between slope aspect, profile and dominant erosional mechanism observed here should be applicable to hillslopes of all aspects within the granitic portion of the catchment.

Talus slopes are predominately thin $(<1 \mathrm{~m})$ veneers of boulder to sand-sized debris above bedrock surfaces, and commonly reach 'critical' slope angles of $45-60^{\circ}$ (Terzaghi, 1962). These observations imply that the talus slopes serve as bridging, equilibrium networks that link cliff faces and long hillslopes to Yudnamutana Creek. Hillslope erosion rates in the Yudnamutana Catchment are therefore set by the rates of (1) bedrock bench lowering via in situ weathering and rock breakup and (2) cliff retreat via rock fall and slab failure.

\section{Valley bottoms}

Within the eastern Yudnamutana Catchment, Yudnamutana Creek maintains a relatively gentle gradient ( 1 m: $275 \mathrm{~m})$ and meandering course (Figure 2). The creek bed consists of a mixture of alluvial bed-load ( $>90 \%$ by area) and bedrock knickpoints $(<10 \%$ by area) that extend several centimeters to $>2 \mathrm{~m}$ above adjacent alluvium. Bed-load consists of sand to boulder-sized ( $>50 \mathrm{~cm}$ diameter) particles dominated by granitic and quartzofeldspathic gneisses derived from granite and quartzite (Figure 2; Coats, 1973). Bedrock knickpoints contain erosional features similar to summit surfaces and bedrock benches but are also channelized and fluted, indicating erosion via weathering, joint 
controlled rock breakup (including plucking during fluvial activity) and abrasion by sediment carried during fluvial activity. A locally outcropping bedrock bench adjacent to Yudnamutana Creek also contains evidence for fluvial abrasion, indicating that this surface is an abandoned strath terrace. Strath surfaces are distinguished from knickpoints in that the former represent abandoned river surfaces, whereas the latter constitute part of the actively eroding creek bed. Some strath surfaces appear to correlate with bedrock knickpoints upstream given similar elevations above the modern creek bed.

\section{Rates of Bedrock Erosion from Cosmogenic ${ }^{10}$ Be Dating}

\section{Theory and methods}

To determine the rates of bedrock erosion in the Yudnamutana Catchment, we collected 14 bedrock samples and one alluvial sediment sample for cosmogenic ${ }^{10} \mathrm{Be}$ analysis. Cosmogenic ${ }^{10} \mathrm{Be}$ forms in near-surface materials by nucleon spallation reactions on $\mathrm{O}$ and to a much lesser extent by negative muon capture and fast muon interactions (Lal, 1991). The in situ production of cosmogenic nuclides $(\mathrm{CNs})$ by nucleons decreases exponentially with depth below the surface, with a mid-latitude penetration length $(\Lambda)$ of $\sim 165 \mathrm{~g} \mathrm{~cm}^{-2}$. This indicates that at depths of $\sim 60 \mathrm{~cm}$ in granitic lithologies the surface production rate has decreased by a factor of e (Gosse and Phillips, 2001). Production due to muon reactions is attenuated more slowly than spallogenic production, and becomes more relevant to total ${ }^{10} \mathrm{Be}$ production at depths greater than $\sim 60 \mathrm{~cm}$ (Masarik and Reedy, 1995).

A general analytical model for interpreting nuclide activities (Lal, 1991) includes two free parameters: a steadystate erosion rate $(E)$ and an exposure time $(t)$. Providing the ${ }^{10} \mathrm{Be}$ production rate at the sample site $(P)$, the ${ }^{10} \mathrm{Be}$ decay rate $(\lambda)$ and the bedrock density $(\rho)$ are known and uniform, the nuclide concentration $(N)$ is defined by

$$
N=\frac{P}{\lambda+E \rho \Lambda^{-1}}\left(1-\mathrm{e}^{-\left(\lambda+E \rho \Lambda^{-1}\right) t}\right)
$$

This model may be rewritten and used in two ways: (1) to calculate an exposure age providing the sampled surface was free of CNs upon exposure (or had CN concentrations of a known amount) and has not eroded or been shielded since exposure $(E=0)$,

$$
t=-\frac{1}{\lambda} \ln \left[1-\frac{N \lambda}{P}\right]
$$

and (2) to calculate an erosion rate providing that $E$ and $P$ have been constant and steady on a timescale relevant to $\mathrm{CN}$ accumulation (1000 to $>10000$ years), so that $N$ is controlled by the rate of mass loss from the sampled surface,

$$
E=\frac{\Lambda}{\rho}\left(\frac{P}{N}-\lambda\right)
$$

$P$ is generally assumed to be constant through time, although variations in the Earth's magnetic field do affect the surface production rate (Clark et al., 1995). We do not address these variations here. Equation (3) can also be used to infer catchment-averaged steady-state erosion rates assuming relatively short transport times and relatively homogeneous catchment lithology (see, e.g., Granger et al., 1996; Bierman and Steig, 1996; Vance et al., 2003; Binnie, 2004).

Samples for ${ }^{10} \mathrm{Be} \mathrm{CN}$ analysis were collected from four different settings in order to determine erosion rates. First, and most simply, the outermost few centimeters of bedrock were sampled from the tops of small tors extending 20$40 \mathrm{~cm}$ above surrounding bedrock and regolith composing summit surfaces and bedrock benches (Figure 4(a) and (b)). We specifically selected horizontal surfaces exhibiting disintegrative or exfoliative weathering and relatively high amounts of desert varnish, thereby attempting to limit our erosion rate approximations to the apparently oldest surfaces exhibiting steady-state erosion. We suspect that the tors emerged because adjacent bedrock surfaces incurred more recent, joint controlled rock breakup and subsequent weathering to regolith.

Second, samples were obtained from fluvially sculpted bedrock surfaces near the base of Yudnamutana Creek. Samples were collected from abandoned strath terraces situated $1.2 \mathrm{~m}$ and $\sim 5.0 \mathrm{~m}$ above the creek floor and from a bedrock knickpoint situated $\sim 0.4 \mathrm{~m}$ above the creek floor (Figures 4 (c) and 6).

Third, stream sediment samples were collected from active stream channels by marking off a small $(<1 \mathrm{~m}$ diameter $)$ area and shoveling $\sim 3-5 \mathrm{~kg}$ of mixed clast types and grain sizes from the sample site into sample bags. Sampled 


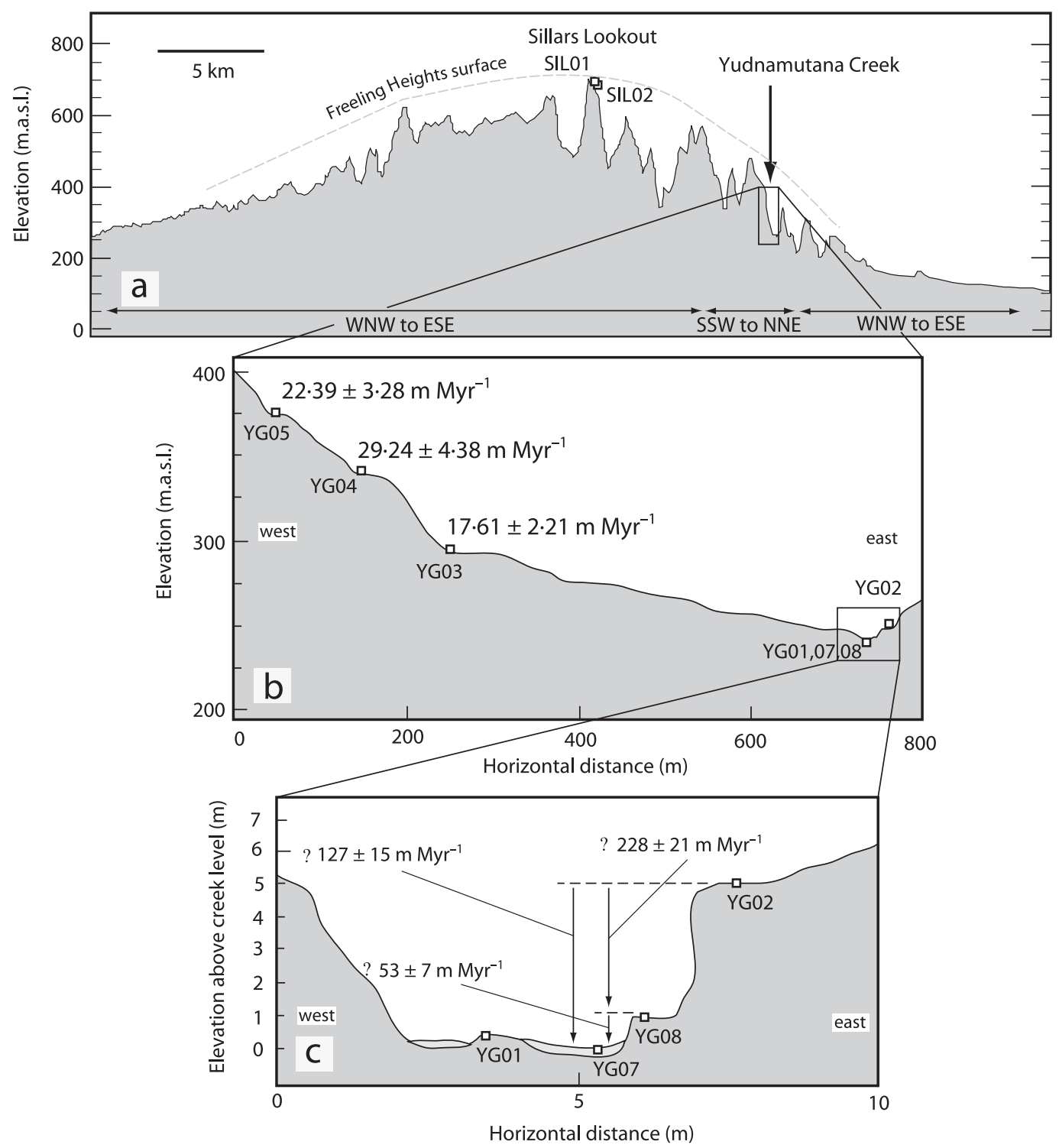

Figure 6. Topographic profiles and cosmogenic sample site locations and erosion rates through the Yudnamutana study area. Location of section (a) shown in Figure 2. Note the position of 'domed' paleo-planation surface represented by the Freeling Heights Surface (Figure 2). (b) Hillslope profile with sample sites. (c) Detailed profile of Yudnamutana Creek with sample sites.

material ranged in grain size from several centimeters to $<1 \mathrm{~mm}$ in diameter. The entire sample was then crushed and the 500-250 $\mu \mathrm{m}$ diameter fraction was isolated, from which quartz was separated. By using this method we attempted to provide a well mixed isotopic inventory of the catchment material irrespective of grain size. ${ }^{10} \mathrm{Be}$ concentrations in river sediment from some catchments have shown an inverse relationship with grain size due to different erosional mechanisms responsible for generating and transporting material of different sizes (Brown et al., 1995, 1998; Matmon et al., 2005). However, in all arid region catchments measured so far, no grain size dependence has been demonstrated (see, e.g., Granger et al., 1996; Clapp et al., 2001).

Finally, pilot samples were collected from subvertical bedrock surfaces extending from the southern and eastern hillslopes of the Yudnamutana Tor (Figure 5). Clearly, the steady-state assumption (Equation (3)) does not apply to these surfaces, given the dominance of joint-controlled large slab delamination (southern face) and block-by-block erosion (eastern face). On the southern face, we sampled the outermost few centimeters of weathered surfaces on slabs 
extending furthest from the spatially averaged cliff face surface (Figure 5(a) and (b)). We chose slabs that contained highly developed detachment surfaces, implying that slab delamination is likely to occur in the near future. Slab surfaces were interpreted to reflect the oldest and most gravitationally unstable parts of the cliff face. On the eastern face, we similarly sampled the most weathered surfaces from the corners of blocks extending furthest from the hillslope (Figure 5(c)). We inferred that both the southern and eastern hillslope samples were likely to have the highest ${ }^{10} \mathrm{Be}$ concentrations on the hillslope, given their apparently old weathering characteristics and extended positions relative to adjacent bedrock surfaces.

Roughly $500 \mathrm{~g}$ of bedrock or sediment was collected from each site. Quartz was separated and purified and ${ }^{10} \mathrm{Be}$ was isolated using standard techniques (Kohl and Nishiizumi, 1992). ${ }^{10} \mathrm{Be}$ concentrations were measured by accelerator mass spectrometry at the Australian National University in Canberra, ACT. Local ${ }^{10} \mathrm{Be}$ surface production rates $(P)$ were calculated using the sea-level, high latitude reference ${ }^{10} \mathrm{Be}$ production rate of $5 \cdot 1 \pm 0 \cdot 3$ atoms g $\mathrm{yr}^{-1}$ (Stone, 2000) rescaled for latitude (Lal, 1991), elevation (Stone, 2000), sample thickness (Gosse and Phillips, 2001) and topographic and geometric shielding (Dunne et al., 1999).

\section{Results}

Summit surface samples from the top of Sillers Lookout and Yudnamutana Tor yield steady-state erosion rates of $13.96 \pm 1.29$ and $14.38 \pm 1.40 \mathrm{~m} \mathrm{Myr}^{-1}$, respectively (Table III, Figure 6). These samples were collected from weathered tor tops and thus corresponding erosion rates provide minimum estimates of the rate of summit surface lowering. We cannot state absolutely that ${ }^{10} \mathrm{Be}$ concentrations in these samples reflect steady-state accumulations; however, the in situ weathering features observed at the sample sites suggest substantial time has passed since a jointcontrolled rock breakup event. We therefore conclude that the bedrock summits in the Yudnamutana region have eroded at rates of $\sim 14 \mathrm{~m} \mathrm{Myr}^{-1}$ in the late Quaternary.

Bedrock bench erosion rates range from $17.61 \pm 2.21$ to $29.24 \pm 4.38 \mathrm{~m} \mathrm{Myr}^{-1}$, and show no systematic relationship with elevation (Table III, Figure 6). The overlap between the slowest bedrock bench erosion rate and summit surface erosion rates quantitatively corroborates our observations that erosional processes are similar in both settings. Variability within the bedrock bench erosion rates most likely reflects differences in the vertical thickness of recently denuded rock fragments and/or differences in time lapsed since rock breakup events. It is possible that some of the rock surfaces yielding higher erosion rates may not yet have reached steady-state $\mathrm{CN}$ concentrations following these events, suggesting that erosion rates be treated as maximum values (see, e.g., Small et al., 1997). Three sites have erosion rates $>20 \mathrm{~m} \mathrm{Ma}^{-1}$, indicating that such events may be more frequent on bedrock benches than on summit surfaces. We infer from our ${ }^{10} \mathrm{Be}$ concentrations that bedrock benches have eroded at similar, but slightly higher rates $\left(\sim 17\right.$ to $\left.\leq 29 \mathrm{~m} \mathrm{Ma}^{-1}\right)$ than summit surfaces.

Strath surface samples yielded exposure ages of $39.23 \pm 4.51 \mathrm{ka}$ for the upper strath and $22.56 \pm 3.08 \mathrm{ka}$ for the lower strath (Table III, Figure 6). We interpret ${ }^{10} \mathrm{Be}$ concentrations from the strath samples in terms of exposure age because these surfaces contain fluvial polish and fluting, indicating that minimal erosion has occurred subsequent to initial incision (see, e.g., Burbank et al., 1996; Reusser et al., 2004; Schaller et al., 2005). We assume that these surfaces remained exposed following incision, i.e. subsequent flooding events and or erosional processes on adjacent hillslopes did not result in long-term burial of knickpoints or straths with sediment. The upper strath surface lies sufficiently high above the present creek bed that flooding events were unlikely to bury this surface; however, we cannot dismiss the possibility that flood events may have episodically buried the lower strath surface. Additionally, we cannot dismiss the possibility that hillslope processes (landsliding, talus creep) as recognized elsewhere within the Yudnamutana Catchment may have buried these surfaces at some point in the past. Exposure ages from the straths are therefore considered minimum ages and resultant incision rates are considered maximum values. Strath and creek bed height-age relationships indicate bedrock incision rates of $\leq 228 \pm 21 \mathrm{~m} \mathrm{Myr}^{-1}$ between $\sim 40$ and $\sim 23 \mathrm{ka}$ and $\leq 53 \pm$ $7 \mathrm{~m} \mathrm{Myr}^{-1}$ from $\sim 23 \mathrm{ka}$ to the present (Figure 6), equating to a time-averaged incision rate of $\leq 127 \pm 15 \mathrm{~m} \mathrm{Myr}^{-1}$.

Sample YG01 was obtained from a bedrock knickpoint surface $\sim 0.4 \mathrm{~m}$ above the creek bed and it is therefore possible that this surface has incurred episodic burial in addition to erosion during late Quaternary flood events (Figure 6). Given this possibility, we are cautious in interpreting the meaningfulness of the low ${ }^{10} \mathrm{Be}$ concentration in this sample. The estimated 98.05 $\pm 54.18 \mathrm{~m} \mathrm{Myr}^{-1}$ erosion rate from this site therefore provides a hypothetical (but geologically plausible) maximum constraint on modern fluvial incision rates in the Yudnamutana Catchment. This in situ rate is within error of the rate determined using strath terrace age.

The stream sediment sample collected from Yudnamutana Creek yielded a spatially averaged catchment erosion rate of $22.79 \pm 2.78 \mathrm{~m} \mathrm{Myr}^{-1}$ (Table III). This value is consistent with the assumption that ${ }^{10} \mathrm{Be}$ concentrations in well mixed, modern stream sediment should be consistent with integrated ${ }^{10} \mathrm{Be}$ concentrations from surfaces throughout the catchment, and thus reflect a spatially averaged erosion rate (Granger et al., 1996; Bierman and Steig, 1996; 


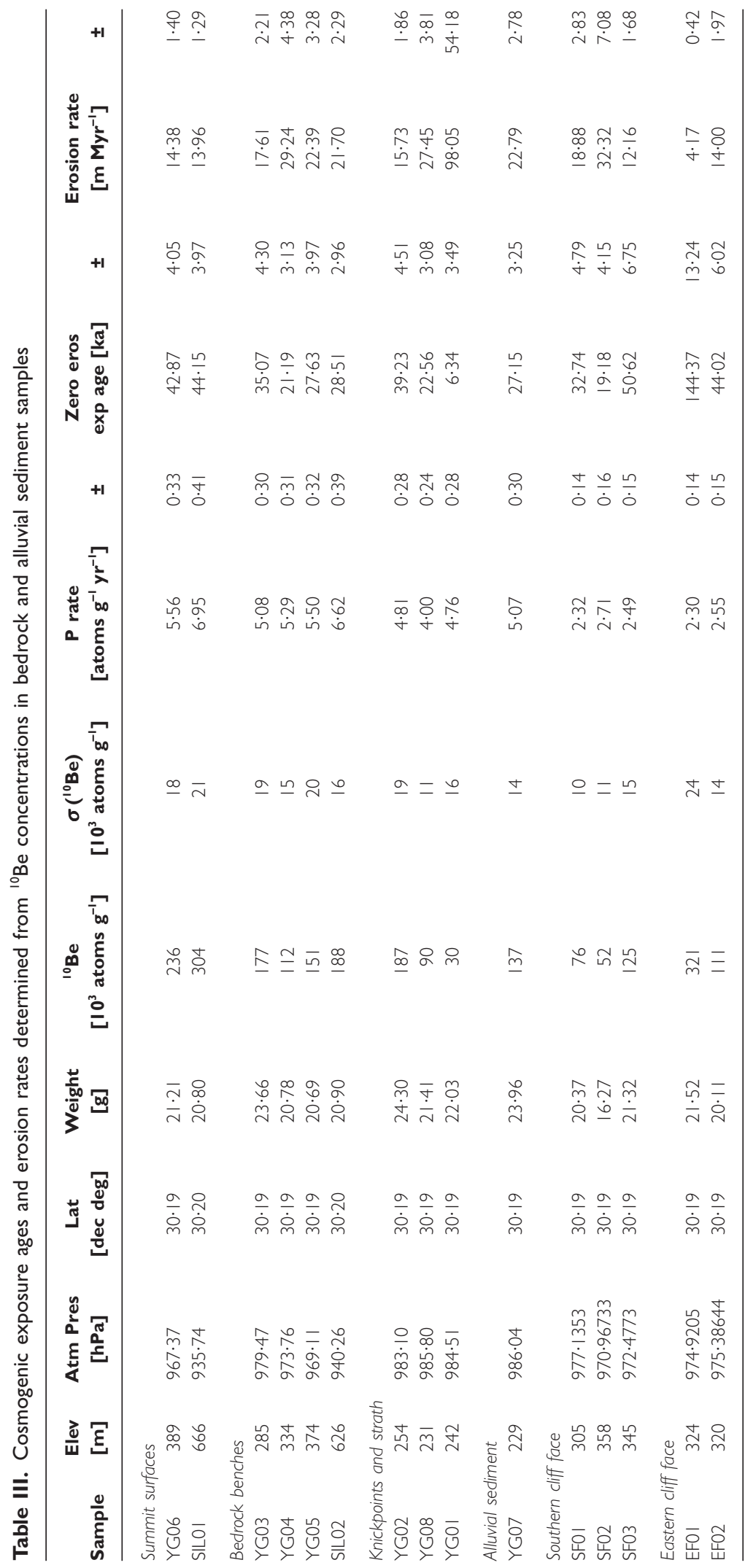


Vance et al., 2003; Binnie, 2004). The catchment erosion rate is higher than summit surface erosion rates, corroborating the observation that in situ bedrock erosion rates are more rapid on catchment hillslopes than at summit surfaces.

Samples collected from the southern cliff face of Yudnamutana Tor yield steady-state erosion rates ranging from $12.16 \pm 1.68$ to $32.32 \pm 7.08 \mathrm{~m} \mathrm{Myr}^{-1}$ (Table III). Samples collected from the east face yield steady-state erosion rates of $4.17 \pm 0.42$ to $14.00 \pm 1.97 \mathrm{~m} \mathrm{Myr}^{-1}$ (Table III). Since hillslope erosion at these sites is dominated by episodic slab delamination and rock fall erosion respectively (Figure 5), the steady-state erosion assumption is clearly invalid. The average bedrock slab thickness from the southern face $(\sim 47 \mathrm{~cm})$ provides a proxy for the thickness of bedrock removed during a 'typical' erosional event. This thickness is roughly equivalent to the penetrative scale length $(\Lambda / \rho)$ for CNs produced by nucleon spallation reactions in unshielded rocks with the density of granite $(\sim 60-65 \mathrm{~cm}$; Brown et al., 1992; Nishiizumi et al., 1994). Since penetrative scale lengths may be significantly shorter in vertical surfaces such as cliff faces (Dunne et al., 1999), we can effectively assume that CN production at the base of slabs prior to delamination is negligible. ${ }^{10} \mathrm{Be}$ concentrations from the outer edges of intact slabs therefore reflect the total ${ }^{10} \mathrm{Be}$ acquired after these surfaces were exposed during an earlier slab-removal event. By selecting slabs for which delamination in the near future is likely, as suggested by well developed fractures along the base of the slabs (Figure 5(b)), then exposure ages from these slabs should provide minimum recurrence intervals of slab delamination events $\left(D_{\text {slab }}\right)$. $D_{\text {slab }}$ can then be combined with average slab thicknesses $\left(t_{\text {slab }}\right)$ to yield a cliff retreat rate $\left(E_{\text {cliff }}\right)$,

$$
E_{\text {cliff }}=\frac{t_{\text {slab }}}{D_{\text {slab }}}
$$

South face cliff retreat rates estimated using this method range from $24.54 \pm 8.53 \mathrm{~m} \mathrm{Myr}^{-1}$ to $9.30 \pm 3.60 \mathrm{~m} \mathrm{Myr}^{-1}$. Since we measured only the apparently oldest slabs extending furthest from the cliff face, we suspect these rates only provide minimum bounds on the rate of cliff retreat across the southern face.

Interpretation of ${ }^{10} \mathrm{Be}$ concentrations from the eastern face samples is significantly more difficult because average spacing between both steep $(\sim 19 \mathrm{~cm})$ and shallow joints $(\sim 20 \mathrm{~cm})$ lies within the spallation penetrative scale length. ${ }^{10} \mathrm{Be}$ concentrations thus reflect non-steady-state accumulations in response to episodic block removal. We interpret these samples in terms of minimum erosion rates because we sampled weathered and varnished vertical faces extending furthest from the hillslope. Modeling of non-steady erosion has been demonstrated to produce $>20$ per cent variability in measured steady-state erosion rates around the actual mean when thicknesses of block removal are similar to our measured joint spacing (Small et al., 1997). We therefore suspect that our calculated rates provide only absolute minimum constraints on the rates of hillslope erosion.

\section{Discussion}

\section{Bedrock erosion and relief production}

Bedrock erosion rates from summits and hillslopes in the Yudnamutana area are similar to erosion rates of $\sim 5-$ $11 \mathrm{~m} \mathrm{Myr}^{-1}$ obtained from quartzites in the central Flinders Ranges (Quigley et al., in review-a), implying that these datasets provide meaningful constraints on the rates of regional bedrock erosion. However, these rates are significantly higher than the low bedrock erosion rates (mostly between $\sim 0.3$ and $3 \mathrm{~m} \mathrm{Myr}^{-1}$ ) obtained from granite inselbergs in the Eyre Peninsula (Figure 1; Bierman and Caffee, 2002). The Eyre Peninsula currently receives more annual rainfall than the northern and central Flinders Ranges (Table I) and the granite lithologies in the Eyre Peninsula should, if anything, be more susceptible to more rapid chemical weathering than the quartz-rich granites and quartzites of the Flinders Ranges. The apparently 'high' erosion rates in the Flinders Ranges must therefore record processes unreflective of annual precipitation or lithology.

Perhaps the most striking difference between low-lying inselbergs and Flinders Ranges bedrock is that the latter is pervasively jointed and fractured while the former is largely intact. Joint spacing appears to be a dominant control on erosion rates for a variety of Australian landforms (see, e.g., Twidale and Campbell, 2005), and the Flinders Ranges appear to be no exception. We suspect that the high joint concentration in the Flinders Ranges is, in part, attributable to the long-lived tectonic history of these rocks (Paul et al., 1999). In addition, regional winter temperatures during late Quaternary glacial periods are likely to have been below freezing over much of the Flinders Ranges, particularly at summit surfaces. During these periods, freeze-thaw erosional processes and frost shattering are likely to have increased bedrock jointing. Once bedrock was pervasively jointed, it was more susceptible to removal during large magnitude flood events and/or seismic shaking (Quigley et al., in review-a). We therefore suspect that the increased bedrock 
erosion rates in the Flinders Ranges reflect late Quaternary climate change, which promoted rock breakup during glacial periods and rock removal during flood events, and tectonics, which promoted rock breakup and removal during seismic events.

If one considers all of the Yudnamutana bedrock erosion rate data, there is considerable variability from site to site despite close proximities and homogeneous sample lithology. Some of this variability is undoubtedly a consequence of differing bedrock spallation thicknesses, inherent in a landscape dominated by episodic erosional processes (see, e.g., Small et al., 1997). However, when coupled with our geomorphic observations, the CN data provide meaningful constraints on the bedrock erosion rates that allow several conclusions to be drawn regarding the temporal and spatial evolution of the Yudnamutana Catchment.

Bedrock incision rates exceed adjacent hillslope and summit surface erosion rates by up to an order in magnitude, indicating that relief within the catchment has increased in the late Quaternary. If the rapid incision rates associated with the last $\sim 40 \mathrm{ka}\left(\sim 127.45 \pm 14.66 \mathrm{~m} \mathrm{Myr}^{-1}\right.$, Figure 6) persisted over longer timescales, the present-day relief between summits and valley floors ( $\sim 37 \mathrm{~m}$, Table III, Figure 6) could have been generated in as little as $\sim 4 \mathrm{Myr}$. While this is undoubtedly an oversimplification, given that erosion and exhumation rates are likely to have varied considerably through time (see, e.g., Mitchell et al., 2002), the currently rapid rates of landscape evolution in the Flinders Ranges are surprising considering that other, nearby landscapes appear to have changed little since the Mesozoic (Bierman and Caffee, 2002). The modern Flinders landscape formed as rapidly eroding canyons dissected an older and lower relief landscape and left behind slowly eroding summits, as documented in other mountainous settings (Small et al., 1997; Riebe et al., 2000).

In order to evaluate whether such dramatic landscape evolution occurred in the Plio-Quaternary, it is critical to examine whether other geological evidence from the region supports such a hypothesis. Thick accumulations of PlioQuaternary sediment in range-bounding alluvial fans indicate that a large volume of sedimentary material was transported out of source catchments over this time. The transition from low-energy lacustrine to coarse clastic sedimentation in these sequences provides sedimentological evidence for an increase in erosion rates and grain size since the terminal Miocene (Callen and Tedford, 1976). The Yudnamutana Catchment incurred significant tectonic uplift in the Plio-Quaternary, as evidenced by neotectonic displacements along the Paralana Fault (Figure 3). Estimates of hangingwall tectonic uplift rate range from 30 to $160 \mathrm{~m} \mathrm{Myr}^{-1}$ (Sandiford, 2003), effectively bracketing our inferred bedrock incision rates. This implies that long-term incision may have operated in concert with uplift. The temporal-spatial coincidence of thick sedimentary sequences, tectonic activity, elevated erosion rates and high relief in the Yudnamutana Catchment implies a causal relationship between Plio-Quaternary tectonic uplift and relief production (Sandiford, 2003). We suggest that tectonic uplift of the Yudnamutana Catchment allowed Yudnamutana Creek to maintain a steep enough gradient to incise into the landscape. Tectonic uplift outpaced erosion lowering at summit surfaces, resulting in increases in elevation and catchment relief. Intriguingly, both the Yudnamutana Catchment and alluvial fans are now steeply incised, implying late Quaternary tectonic uplift has also occurred on a broader wavelength, encompassing both the ranges and bounding piedmonts (Célérier et al., 2005).

Apatite fission track ages from the Yudnamutana region range from Middle Paleozoic to Eocene and limit the total amount of Late Cretaceous to Recent denudation to 1-2 km (Mitchell et al., 2002). Mitchell et al. (2002) attributed this exhumation to range uplift and denudation in the early Tertiary based on one fission track age from the Paralana Fault Zone. However, it is unclear whether this sample cooled in response to exhumation or decreases in the local geothermal gradient (Mitchell et al., 2002). Alternatively, Gibson and Stüwe (2000) noted that the post 25 Ma cooling recorded by apatite fission track data occurred throughout the broader region, and was not limited to the present-day ranges. These workers inferred that range uplift occurred after apatite fission track cooling below temperatures of $\sim 50-70{ }^{\circ} \mathrm{C}$.

Recent work suggests that a large component of range uplift occurred in the Plio-Quaternary (Sandiford, 2003; Quigley et al., 2006a). Uplift occurred in response to east-west oriented contractional forces interpreted as intraplate manifestations of far-field stresses generated at Australian plate margins (Sandiford, 2003; Célérier et al., 2005; Quigley et al., 2006a). Sandiford (2003) and Sandiford et al. (2004) traced this regime back to the terminal Miocene to Early Pliocene, based on regional Miocene-Pliocene unconformities, uplifted Miocene limestones, terminal Miocene changes in plate boundary kinematics and plate-scale numerical modeling. Although the total magnitude of PlioQuaternary surface uplift requires further investigation, cosmogenic data from the northern Flinders Ranges confirm the hypothesis that a significant component of the modern landscape reflects Plio-Quaternary tectonism.

\section{River incision and climate change}

Regardless of the magnitudes of tectonic uplift, relief could not have developed without the necessarily climatic conditions to facilitate fluvial incision. In order to incise into bedrock, rivers must transport their bedload, which in 
this case is primarily composed of coarse material. The large component of coarse material in the creek bed and alluvial fans down-stream from the study area indicates that movement of this material occurs. Transport of coarse material requires large stream discharges as would be associated with large magnitude floods. Since Yudnamutana Creek is highly ephemeral, such flooding and consequent incision must have occurred as a series of punctuated events, as opposed to 'steady-state' erosion. Incision of this magnitude involved both abrasion by coarse transported bedload and plucking of weathered or jointed bedrock (see, e.g., Hancock et al., 1998; Whipple et al., 2000). It is therefore apparent that the temporal distribution of incision events in the Yudnamutana Catchment was governed by the frequency of large magnitude flood events, as described for other mountainous catchments around the globe (Molnar, 2001; Kirchner et al., 2001).

Quigley et al. (2006b) concluded that four large magnitude flood events had occurred at $~ 1500$ year intervals since $6 \mathrm{ka}$ in the central Flinders Ranges, based on compiled optically stimulated luminescence and ${ }^{14} \mathrm{C}$ chronology from aggraded alluvial fan sequences. Alluvial sequences in central Flinders Ranges catchments have been incised by as much as 10-18 m since the LGM (Williams et al., 2001; Quigley et al., 2006a). Given the inferred large magnitude of these events, Quigley et al. (2006b) suggested that these Holocene flood events were likely to be regional in extent. Such large magnitude flooding may well have been responsible for the $1.2 \mathrm{~m}$ of bedrock incision in the Yudnamutana Creek since $\sim 23 \mathrm{ka}$.

Our data suggest that the most rapid phase of incision for Yudnamutana Creek occurred between formation of the strath terrace and upper knickpoint at $\sim 40-23 \mathrm{ka}$ (Figure 6). At this time, climatic conditions may have differed from today, with air temperatures at least $9{ }^{\circ} \mathrm{C}$ colder than present (Miller et al., 1997). Prior to this interval (65-45 ka), the region incurred numerous short-lived climatic oscillations and enhanced periods of significant monsoonal rainfall (Johnson et al., 1999). Subsequent to this interval (28-15 ka), climatic variability and monsoonal rainfall was significantly reduced and large magnitude floods were less frequent (Johnson et al., 1999; Williams et al., 2001). We therefore infer that rapid incision in the Yudnamutana Catchment occurred during colder but more climatically variable conditions punctuated by brief but dramatic incursions of summer monsoonal precipitation and large flood events. Increased rates of incision may have been prompted by (1) higher rates of in situ chemical weathering of granitic bedrock due to increased precipitation, including feldspar hydrolysis, (2) higher rates of in situ physical weathering and breakup of bedrock due to increased precipitation and colder temperatures, including frost shattering, and/or (3) increased frequency-magnitude distributions of large magnitude floods capable of transporting coarse bedload and incising bedrock. Alluvial fan building occurred in parts of central Flinders Ranges prior to and during this time ( 80-29 ka), suggesting that increased catchment erosion rates may have been recorded by increased rates of sedimentation along range fronts (Williams, 1973; Quigley et al., 2006a, in review-a). Thick sequences of fine-grained sediment accumulated in lower-elevation, shale-limestone-sandstone-dominated catchments around the time of the LGM ( 33-17 ka; Williams et al., 2001). This suggests that variations in bedrock lithology and/or topography may have resulted in significantly different catchment responses during times of lesser climatic variability and less frequent flood events.

\section{Conclusions}

Cosmogenic ${ }^{10} \mathrm{Be}$ erosion-rate estimates indicate that fluvial incision has outpaced summit surface and hillslope erosion in the Yudnamutana Catchment in the late Quaternary. Linear extrapolation of these rates over longer timescales indicates that the rugged topographic relief currently characterizing the northern Flinders Ranges could have formed in as little as 4 Myr. This dramatic conclusion is supported by the sedimentary record, which contains evidence for a transition to coarse, high-energy sedimentation along the range front at the start of the Pliocene, and the neotectonic record of faulting, which provides evidence for more than $150 \mathrm{~m}$ of tectonic uplift over this time. Tectonic uplift generated relief by sustaining a steep enough gradient to maintain fluvial incision and by uplifting adjacent summit surfaces relative to the valley floor. Climate change episodically increased both in situ bedrock weathering rates and frequency-magnitude distributions of large magnitude floods, resulting in increased bedload transport and fluvial incision. The Australian landscape is not ubiquitously 'low, flat and old' and may in fact be quite youthful and dynamic, particularly in regions subjected to Plio-Quaternary tectonic activity.

\section{Acknowledgments}

We thank anonymous reviewers for comments that improved this manuscript. Tom Fromhold and Anna Sandiford are thanked for their assistance in collecting field data. 


\section{References}

Australian Bureau of Meteorology. 2006. www.bom.gov.au [accessed 3 March 2006].

Belperio AP. 1995. Quaternary. In The Geology of South Australia Volume 2, The Phanerozoic, Drexel JF, Preiss WV (eds). South Australian Geological Survey Bulletin 54: 219-281.

Belton DX, Brown RW, Kohn BP, Fink D, Farley KA. 2004. Quantitative resolution of the debate over antiquity of the central Australian landscape: implications for the tectonics and geomorphic stability of cratonic interiors. Earth and Planetary Science Letters 219: 21-34.

Bierman PR, Caffee M. 2002. Cosmogenic exposure and erosion history of Australian bedrock landforms. Geological Society of America Bulletin 114: 787-803.

Bierman PR, Steig E. 1996. Estimating rates of denudation and sediment transport using cosmogenic isotope activities in sediment. Earth Surface Processes and Landforms 21: 25-139.

Binnie S. 2004. Deriving Basin-Wide Denudation Rates from Cosmogenic Radionuclides, San Bernardino Mountains, California. Unpublished PhD thesis, The University of Edinburgh.

Brown ET, Brook EJ, Raisbeck GM, Yiou F, Kurz M. 1992. Effective attenuation lengths of cosmic rays producing ${ }^{10} \mathrm{Be}$ and ${ }^{26} \mathrm{Al}$ in quartz; implications for exposure age dating. Geophysical Research Letters 19(4): 369-372.

Brown ET, Stallard RF, Larsen MC, Bourles DL, Raisbeck GM, Yiou F. 1998. Determination of predevelopment denudation rates of an agricultural watershed (Cayaguas River, Puerto Rico) using in-situ-produced ${ }^{10} \mathrm{Be}$ in river-borne quartz. Earth and Planetary Science Letters 160(3/4): 723-728.

Brown ET, Stallard RF, Larsen MC, Raisbeck GM, Yiou F. 1995. Denudation rates determined from the accumulation of in situ-produced ${ }^{10} \mathrm{Be}$ in the Luquillo experimental forest, Puerto Rico. Earth and Planetary Science Letters 129(1-4): 193-202.

Burbank DW, Leland J, Fielding E, Anderson RS, Brozovic N, Reid MR, Duncan C. 1996. Bedrock incision, rock uplift, and threshold hillslopes in the northwestern Himalayas. Nature 379: 505-510.

Callen RA, Tedford RH. 1976. New late Cainozoic rock units and depositional environments, Lake Frome Area, South Australia. Transactions of the Royal Society of South Australia 100: 125-167.

Célérier J, Sandiford M, Lundbek D, Quigley M. 2005. Modes of active intraplate deformation, Flinders Ranges, Australia. Tectonics 24. DOI: $10.029 / 2004 \& C 001679$

Clapp EM, Bierman PR, Nichols KK, Pavich MJ, Caffee M. 2001. Rates of sediment supply to arroyos from upland erosion determined using in situ produced cosmogenic ${ }^{10} \mathrm{Be}$ and ${ }^{26} \mathrm{Al}$. Quaternary Research 55(2): 235-245.

Clark DH, Bierman PR, Larsen P. 1995. Improving in situ cosmogenic chronometers. Quaternary Research 44(3): 367-377.

Clark DJ, Leonard M. 2003. Principal stress orientations from multiple focal plane solutions: new insight into the Australian intraplate stress field. In Evolution and Dynamics of the Australian Plate, Hillis RR, Muller D (eds). Geological Society Australia Special Publication 22: 85-99.

Coats RP (compiler). 1973. Copley, South Australia. Geological Survey of South Australia, Geological Series Explanatory Notes, Sheet SH/ 54-9.

Dunne J, Elmore D, Muzikar P. 1999. Scaling factors for the rates of production of cosmogenic nuclides for geometric shielding and attenuation at depth on sloped surfaces. Geomorphology 27: 3-11.

Fenner C. 1933. Physiographic features of Australia and New Zealand; South Australia. Australia and New Zealand Association for Advancement of Science Repository from 21 st Meeting, 470-472.

Gallagher K, Dumitru T, Gleadow A. 1994. Constraints on the vertical motion of eastern Australia during the Mesozoic. Basin Research 6: 77-94.

Gibson HJ, Stüwe, K. 2000. Multiphase cooling and exhumation of the southern Adelaide Fold Belt: constraints from apatite fission track data. Basin Research 12: 31-45.

Gosse JC, Phillips FM. 2001. Terrestrial in situ cosmogenic nuclides: theory and application. Quaternary Science Reviews 20: 1475-1560.

Granger DE, Kirchner JW, Finkel RC. 1996. Spatially averaged long-term erosion rates measured from in situ-produced cosmogenic nuclides in alluvial sediment. Journal of Geology 104: 249-257.

Greenhalgh SA, Love D, Malpas K, McDougall R. 1994. South Australian earthquakes, 1980-92. Australian Journal of Earth Sciences 41: 483-495.

Hancock GS, Anderson RS, Whipple KX. 1998. Beyond power: bedrock river incision process and form. In Rivers Over Rock: Fluvial Processes in Bedrock Channels, Tinkler K, Wohl EE (eds). American Geophysical Union Geophysical Monograph 107: 35-60.

Johnson BJ, Miller GH, Fogel ML, Magee JW, Gagan MK, Chivas AR. 1999. 65000 years of vegetation change in central Australia and the Australian summer monsoon. Science 284(5417): 1150-1152.

Kirchner JW, Finkel RC, Riebe CS, Granger DE, Clayton JL, King JG, Megahan WF. 2001. Mountain erosion over 10 yr, 10 k.y., and 10 m.y. time scales. Geology 29(7): 591-594.

Kohl CP, Nishiizumi K. 1992. Chemical isolation of quartz for measurement of in-situ-reduced cosmogenic nuclides. Geochimica et Cosmochimica Acta 56: 3583-3587.

Lal D. 1991. Cosmic ray labeling of erosion surfaces: in situ nuclide production rates and erosion models. Earth and Planetary Science Letters 104: 424-439.

Masarik J, Reedy RC. 1995. Terrestrial cosmogenic nuclide production systematics calculated from numerical simulations. Earth and Planetary Science Letters 136: 381-395.

Matmon A, Bierman PR, Larson J, Southworth S, Pavich M, Finkel RC, Caffee M. 2005. Grain size dependency of ${ }^{10}$ Be concentrations in alluvial sediments in the Great Smoky Mountains. Geochimica et Cosmochimica Acta 69(10): 160. 
Miller GH, Magee, JW, Jull AJT. 1997. Low-latitude glacial cooling in the Southern Hemisphere from amino-acid racemization in emu eggshells. Nature 385: 241-244.

Mitchell MM, Kohn BP, O’Sullivan PB, Hartley MJ, Foster, DA. 2002. Low-temperature thermochronology of the Mt Painter Province, South Australia. Australian Journal of Earth Sciences 49: 551-563.

Molnar P. 2001. Climate change, flooding in arid environments, and erosion rates. Geology 29: 1071-1074.

Nishiizumi K, Finkel RC, Caffee MW, Southon JR, Kohl CP, Arnold JR, Olinger CT, Poths J, Klein J. 1994. Cosmogenic production of ${ }^{10}$ Be and ${ }^{26} \mathrm{Al}$ on the surface of the earth and underground. Eighth International Conference on Geochronology, Cosmochronology and Isotope Geochemistry. U.S. Geological Survey Circular 1107: 234.

Ollier CD. 1978. Tectonics and geomorphology of the Eastern Highlands. In Landform Evolution in Australia, Davies JL, Williams MAJ (eds). ANU Press: Canberra; 5-47.

Paul E, Flottmann T, Sandiford M. 1999. Structural geometry and controls on basement-involved deformation in the northern Flinders Ranges, Adelaide Fold Belt, South Australia. Australian Journal of Earth Sciences 46: 343-354.

Preiss WV. 1999. Explanatory notes for the PARACHILNA 1:250 000 geological map. MESA Journal 14: 27-29.

Quigley M, Cupper M, Sandiford M. 2006a. Quaternary faults of south-central Australia: palaeoseismicity, slip rates and origin. Australian Journal of Earth Sciences 53: 315-331.

Quigley M, Sandiford M, Alimanovic A, Fifield K. In review-a. Geomorphic expressions of active intraplate deformation, Flinders Ranges, South Australia. Geology.

Quigley M, Sandiford M, Cupper M. In review-b. Distinguishing tectonic from climatic controls on range-front sedimentation. Basin Research.

Quigley M, Sandiford M, Cupper M. 2006b. Landscape expressions of late Quaternary climate change and large flood events, Flinders Ranges, South Australia. Geological Society of Australia 2006 Earth Sciences Convention Program With Abstracts.

Reusser LJ, Bierman PR, Pavich MJ, Zen E, Larsen J, Finkel R. 2004. Rapid late Pleistocene incision of Atlantic passive-margin river gorges. Science 305: 499-502.

Riebe CS, Kirchner JW, Granger DE, Finkel RC. 2000. Erosional equilibrium and disequilibrium in the Sierra Nevada, inferred from cosmogenic ${ }^{26} \mathrm{Al}$ and ${ }^{10} \mathrm{Be}$ in alluvial sediment. Geology 28(9): 803-806.

Sandiford M. 2003. Neotectonics of southeastern Australia: linking the Quaternary faulting record with seismicity and in situ stress. In Evolution and Dynamics of the Australian Plate, Hillis RR, Muller D (eds). Geological Society of Australia, Special Publication 22: 101113.

Sandiford M, Wallace M, Coblentz D. 2004. Origin of the in situ stress field in southeastern Australia. Basin Research 16: $325-338$.

Schaller M, Hovius N, Willett SD, Ivy-Ochs S, Synal H, Chen M. 2005. Fluvial bedrock incision in the active mountain belt of Taiwan from in situ-produced cosmogenic nuclides. Earth Surface Processes and Landforms 30: 955-971.

Small EE, Anderson RS, Repka JL, Finkel R. 1997. Erosion rates of alpine bedrock summit surfaces deduced from in situ ${ }^{10} \mathrm{Be}$ and ${ }^{26} \mathrm{Al}$. Earth and Planetary Science Letters 150: 413-425.

Sprigg RC. 1945. Some aspects of the geomorphology of a portion of the Mount Lofty Ranges. Transactions of the Royal Society of South Australia 69: 277-304.

Stevens BPJ, Corbett GJ. 1993. The Redan geophysical zone; part of the Willyama Supergroup? (Broken Hill, Australia). Australian Journal of Earth Sciences 40: 319-338.

Stock GM, Anderson RS, Finkel RC. 2005. Rates of erosion and topographic evolution of the Sierra Nevada, California, inferred from cosmogenic ${ }^{26} \mathrm{Al}$ and ${ }^{10} \mathrm{Be}$ concentrations. Earth Surface Processes and Landforms 30: 985-1006.

Stone JO. 2000. Air pressure and cosmogenic isotope production. Journal of Geophysical Research 105: 23 753-23 759.

Terzaghi K. 1962. Stability of steep slopes on hard unweathered rock. Geotechnique 12(4): 251-270.

Twidale CR. 1994. Gondwanan (Late Jurassic and Cretaceous) palaeosurfaces of the Australian Craton. Palaeogeography, Palaeoclimatology, Palaeoecology 112: 157-186.

Twidale CR. 2000. Early Mesozoic (?Triassic) landscapes in Australia: evidence, argument and implications. Journal of Geology 108: 537552.

Twidale CR, Bourne JA. 1975. Geomorphological evolution of part of the eastern Mount Lofty Ranges, South Australia. Transactions of the Royal Society of South Australia 99(4): 197-209.

Twidale CR, Campbell EM. 2005. Australian Landforms: Understanding a Low, Flat, Arid and Old Landscape. Rosenberg: Kenthurst, NSW.

Vance D, Bickle M, Ivy-Ochs S, Kubick PW. 2003. Erosion and exhumation in the Himalaya from cosmogenic isotope inventories of river sediments. Earth and Planetary Science Letters 206: 273-288.

Veevers JJ, Conaghan PJ. 1984. Phanerozoic Earth History of Australia. Clarendon-Oxford University Press: Oxford.

Whipple KX, Hancock GS, Anderson RS. 2000. River incision into bedrock: mechanics and relative efficacy of plucking, abrasion, and cavitation. Geological Society of America Bulletin 112: 490-503.

Williams GE. 1973. Late Quaternary piedmont sedimentation, soil formation and palaeoclimates in arid South Australia. Zeitschrift für Geomorphologie 17: 102-125.

Williams M, Prescott J, Chappell J, Adamson D, Cock B, Walker K, Gell P. 2001. The enigma of a late Pleistocene wetland in the Flinders Ranges, South Australia. Quaternary International 83-85: 129-144. 